\title{
Pengaruh perbedaan konsentrasi olahan air lindi terhadap kelimpahan Chlorella sp
}

\author{
Rosyadi $^{1^{*}}$, Agusnimar $^{2}$, Hisra Melati ${ }^{3}$ \\ ${ }^{1,2,3}$ Program Studi Budidaya Perairan Fakultas Pertanian Universitas Islam Riau \\ *Koresponden E-mail: rosyadi@agr.uir.ac.id
}

(Diterima; 25 November 2021|Disetujui: 28 Desember 2021|Diterbitkan: 31 Januari 2022)

\begin{abstract}
Leachate, as liquid waste is rich in nutrients, can be used as organic material for the microalgae culture such as Chlorella sp. This study aims to determine the effect of different concentrations to of leachate on the abundance of Chlorella sp populations. The observation was conducted at the laboratory of Microalgae, Agriculture faculty, Islamic University of Riau. The method used in this study was an experimental method using a randomized design; one factor, namely the different concentrations ofleachate with five levels, were 5\%, $10 \%, 15 \%, 20 \%$, and $25 \% / l$ of water and three replications. The testing organism in this study was phytoplankton Chlorella sp. The culture container used was a gallon with $20 \mathrm{~L}$ of capacity and a water volume of $16 \mathrm{~L}$. The measured parameters were cell abundance, specific growth rate, and water quality. The obtained results showed that the highest abundance of Chlorella sp at a concentration of $25 \%$ at 7,322,222 cells $/ \mathrm{ml}$, and the peak on day 16, the lowest concentration of 5\%, was 2,580,556 cells/ml. On the sixth day, the highest specific growth rate was at a concentration 5\% at 0.195/day, and the lowest was 20\% at 0.077/day.
\end{abstract}

Keywords: microalgae; culture media; leachate; EM4; growth

\section{PENDAHULUAN}

Sebagai daerah tropis Indonesia memiliki potensi sumberdaya alam yang besar untuk dikembangkan, terutama pengembangan sumberdaya alam akuatik, seperti mikroalga yang memanfaatkan energi untuk proses fotosintesis. Mikroalga jenis Chlorella sp merupakan mikroorganisme bersel tunggal dari golongan alga hijau termasuk dalam filum Chlorophyta, memiliki nilai gizi tinggi dan mudah untuk dikultur.

Chlorella sp memiliki kandungan protein, karbohidrat, lemak, vitamin dan mineral memberikan berbagai alternatif, yang pemanfaatannya sebagai sumber bahan pangan untuk manusia maupun sebagai bahan pakan untuk ternak dan ikan atau sebagai sumber biofuel. Sugiharto (2020), melaporkan bahwa, Chlorella vulgaris memiliki kandungan protein kasar $55,3 \%$, lemak kasar $10,3 \%$ dan serat kasar 5,80\%.

Chlorella sp memiliki peluang sangat besar untuk dibudidayakan, karena memiliki sifat yang mudah dan cepat berkembangbiak. Untuk menghasilkan sel Chlorella sp dalam jumlah besar, diperlukan unsur hara atau media kultur yang sesuai untuk pertumbuhan dan bereproduksi. Unsur hara tersebut bisa dalam bentuk pupuk komersial, limbah cair atau padat yang mengandung materi organik.

Keberadaan air lindi yang ada di tempat pembuangan akhir (TPA) sampah, sampai saat ini belum banyak dimanfaatkan sebagai sumber materi organik. Air lindi merupakan air dengan kandungan bahan organik yang kaya nutrien dan terbentuk dalam tempat penimbunan (landfill) sampah, akibat adanya air hujan yang masuk ke dalam landfill. Pada hal air lindi memiliki potensi sebagai sumber materi organik yang dapat dimanfaatkan oleh tanaman termasuk mikroalga jenis Chlorella sp. Sementara bila tidak dimanfaatkan, air lindi dapat mencemari air sekitar tempat pembuangan akhir sampah, sehingga menyebabkan penurunan kualitas lingkungan. Mikroalga jenis Chlorella sp memiliki kemampuan hidup pada perairan tercemar dan dapat menyerap unsur hara dengan kandungan tinggi seperti pada air lindi.

Kelimpahan sel Chlorella sp sangat tergantung pada ketersediaan materi organik dan kondisi lingkungan. Air lindi yang berasal dari hasil dekomposisi sampah di tempat pembuangan akhir (TPA) sampah, mengandung banyak unsur-unsur hara yang dapat dimanfaatkan untuk pertumbuhan dan pembiakan mikroalga. Menurut Dimiati \& Hadi (2017), air lindi banyak mengandung unsur-unsur hara yang dibutuhkan tanaman, diantaranya organik nitrogen, amonium nitrogen, nitrat, fosfor dan total besi.

Selama ini belum banyak penelitian yang membahas tentang potensi atau pemanfaatan air lindi dengan cara penyaringan yang difermentasi EM4 sebagai sumber materi organik untuk kultur Chlorella sp. Berdasarkan urairan di atas, maka dilakukan penelitian untuk mencari informasi tentang pertumbuhan sel Chlorella sp yang dikultur pada air lindi dengan penyaringan dan konsentrasi berbeda yang difermentasi EM4. 


\section{BAHAN DAN METODE}

\section{Bahan dan alat}

Bibit Chlorella sp diperoleh dari stok murni di Laboratorium Mikroalga dan Nutrisi Fakultas Pertanian Universitas Islam Riau, Pekanbaru. Materi organik yang digunakan sebagai unsur hara adalah air lindi, diperoleh dari tempat pembuangan akhir (TPA) sampah di Muara Fajar, Rumbai kota Pekanbaru. Bahan fermentasi digunakan Efektif Mikroorganisme (EM4) dan sebagai media kultur digunakan air sumur bor. Peralatan utama kultur antara lain, gallon, lampu neon, aerator, mikroskop binokuler dan komputer, plankton net, haemacytometer, micropipet, timbangan analitik, sentrifuse, oven, $\mathrm{pH}$ meter, thermometer, DO meter dan alat-alat gelas.

\section{Metode penelitian}

Metode yang digunakan adalah metode eksperimen, dengan Rancangan Acak Lengkap (RAL) dengan 1 taraf dan 5 perlakuan serta 3 perulangan. Adapun perlakuan yang digunakan adalah konsentrasi air lindi meliputi, $\mathrm{P} 1=5 \%, \mathrm{P} 2=10 \%, \mathrm{P} 3=15 \%, \mathrm{P} 4=20 \%$ dan $\mathrm{P} 5=25 \% / \mathrm{L}$ air. Sumber materi organik pada penelitian ini menggunakan air lindi yang diolah dengan penyaringan yang difermentasi EM4, dan sebagai media kultur digunakan air sumur bor. Jumlah media tiap gallon sebanyak $16 \mathrm{~L}$, dengan kepadatan awal sel Chlorella sp sebanyak $306 \times 10^{3} \mathrm{sel} / \mathrm{ml}$. Penghitungan kelimpahan sel dilakukan tiap dua hari sekali, pengukuran kualitas air seperti suhu diukur dua hari sekali, untuk $\mathrm{pH}$, oksigen terlarut (DO), nitrat, fosfat, COD dan BOD diukur setiap lima hari sekali. Analisa air lindi dilakukan di laboratorium kualitas air Faperika Unri dan laboratorium Central Plantation Services Pekanbaru.

\section{Analisis data}

Untuk menghitung jumlah kelimpahan sel Chlorella sp digunakan alat haemacytometer tipe neubauer, dengan rumus menurut (Mukhlis et al., 2017): $\mathrm{N}=\mathrm{n} \times 10^{4}(\mathrm{sel} / \mathrm{ml})$; dimana $\mathrm{N}$ adalah total sel hasil perhitungan $(\mathrm{sel} / \mathrm{ml}), \mathrm{n}$ adalah jumlah total $\mathrm{sel} / \mathrm{ml}$ pada setiap sampel. Laju pertumbuhan spesifik $(\mu)$ dihitung dengan rumus menurut Wood et al., (2005): $\mu=\operatorname{Ln}\left(\mathrm{N}_{2} / \mathrm{N}_{1}\right) / \mathrm{t}_{2}-\mathrm{t}_{1}$; dimana $\mathrm{N}_{2}$ adalah kepadatan populasi pada waktu ke-t, $\mathrm{N}_{1}$ adalah kepadatan populasi sel pada waktu ke- $0, \mathrm{t}_{1}=$ waktu awal dan $\mathrm{t}_{2}=$ waktu pengamatan (hari). Pengaruh perbedaan konsentrasi air lindi terhadap pertumbuhan sel Chlorella sp diuji dengan menggunakan analisis variansi (Anava) menurut (Steel \& Torrie, 1993).

\section{HASIL DAN PEMBAHASAN}

\section{Kelimpahan sel Chlorella sp}

Hasil penghitungan kelimpahan sel Chlorella sp selama penelitian disajikan dalam bentuk grafik pada Gambar 1.

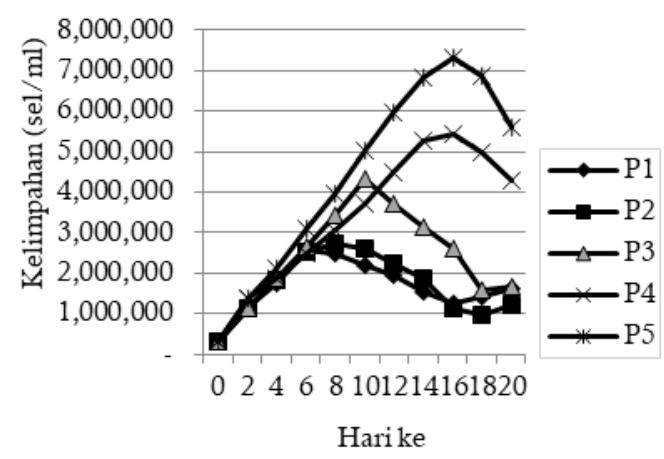

Gambar 1. Grafik kelimpahan sel Chlorella sp (sel/ml) menurut perlakuan dan hari pengukuran.

Pada awal kultur pertumbuhan sel tidak mengalami fase lag, namun sudah memasuki fase ekponensial. Hal ini dikarenakan pada saat dilakukan kultivasi stok kultur sudah berada pada fase ekponensial, sehingga sel-sel yang diinokulasikan dapat beradaptasi terhadap media kultur yang baru. Istirokhatun et al., (2017), mengatakan fase adaptasi akan menjadi lebih singkat atau bahkan tidak terlihat apabila sel-sel yang diinokulasikan berasal dari kultur yang berada dalam fase eksponensial.

Pertumbuhan sel Chlorella sp untuk seluruh perlakuan hingga pengukuran hari ke-6 kecepatan tumbuhnya hampir sama, ini menunjukkan mikroalga dapat menyerap materi organik pada media kultur. Namun untuk konsentrasi 5\% dan 10\% pada hari ke-8 dan ke-10 kelimpahannya sudah mulai mengalami penurunan. Hal ini disebabkan karena dengan pemberian konsentrasi air lindi yang rendah, materi organik yang ada tidak terpenuhi untuk kebutuhan pertumbuhan sel, sehingga kelimpahan sel mikroalga mulai mengalami penurunan dan memasuki fase kematian. Meritasari (2012), fase kematian terjadi ketika sel mikroalga mulai mati, ditandai dengan menurunnya kelimpahan sel. Kematian sel mikroalga dapat terjadi karena adanya perubahan kualitas air kearah yang buruk, kondisi lingkungan tidak lagi menguntungkan, umur kultivasi yang terlalu lama dan terjadi penurunan kandungan nutrisi dalam media kultivasi.

Pemberian air lindi dengan penyaringan yang difermentasi EM4, pada konsentrasi $20 \%$ dan $25 \%$ pertumbuhannya mengalami peningkatan hingga hari ke-16. Peningkatan pertumbuhan sel mikroalga terjadi karena materi organik pada air lindi difermentasi oleh mikroorganisme aerob maupun anaerob, sehingga unsur hara akan lebih cepat terurai dan diserap oleh mikroalga. Dari penelitian dengan memanfaatkan air lindi dengan penyaringan, kelimpahan sel mikroalga lebih tinggi pada air lindi konsentrasi 5\% dan 10\%, karena dengan difermentasi materi organik lebih cepat mengurai dan diserap, sehingga ketersediaan unsur hara lebih cepat menurun dan tidak mencukupi untuk pertumbuhan sel mikroalga. Mujiatul (2013), fermentasi merupakan proses yang dilakukan oleh 
mikroorganisme baik aerob maupun anaerob, yang mampu mengubah atau mentransformasikan senyawa kimia kompleks menjadi lebih sederhana, yang bertujuan untuk mempercepat penyerapan nutrisi pada tanaman.

Ditingkatkannya konsentrasi air lindi dengan penyaringan yang difermentasi EM4, menyebabkan kelimpahan sel Chlorella sp mengalami peningkatan. Pemberian air lindi konsentrasi 25\% kelimpahannya lebih besar dibanding konsentrasi $20 \%$ atau $15 \%$. Pertumbuhan sel mikroalga sangat ditentukan oleh keberadaan unsur hara dalam media kultur, seperti unsur nitrat. Liu et al., (2015) melaporkan bahwa, dengan penambahan nitrat dalam media kultur mampu meningkatkan pertumbuhan sel mikroalga jenis Chlorella ellipsoidea menjadi lebih banyak dibandingkan dengan tanpa penambahan nitrat.

Tabel 1. Data kelimpahan sel Chlorella $\mathrm{sp}\left(\times 10^{3} \mathrm{sel} / \mathrm{ml}\right)$ selama penelitian.

\begin{tabular}{cccccc}
\hline \multirow{2}{*}{$\begin{array}{c}\text { Kari } \\
\text { ke }\end{array}$} & \multicolumn{5}{c}{ Perlakuan/kelimpahan (sel/mL) } \\
\cline { 2 - 6 } 0 & $\begin{array}{c}\mathrm{P} 2 \\
(5 \%)\end{array}$ & $(10 \%)$ & $(15 \%)$ & $(20 \%)$ & $\begin{array}{c}\mathrm{P} 5 \\
(25 \%)\end{array}$ \\
2 & 306 & 306 & 306 & 306 & 306 \\
2 & 1.183 & 1.147 & 1.141 & 1.375 & 1.366 \\
4 & 1.755 & 1.833 & 1.863 & 1.880 & 2.130 \\
6 & 2.580 & 2.511 & 2.641 & 2.472 & 3.091 \\
8 & 2.472 & 2.725 & 3.433 & 3.061 & 3.961 \\
10 & 2.200 & 2.616 & 4.316 & 3.705 & 5.038 \\
12 & 1.944 & 2.230 & 3.708 & 4.475 & 5.972 \\
14 & 1.550 & 1.866 & 3.130 & 5.255 & 6.811 \\
16 & 1.233 & 1.116 & 2.616 & 5.427 & 7.322 \\
18 & 1.425 & 966 & 1.577 & 4.977 & 6.861 \\
20 & 1.625 & 1.191 & 1.677 & 4.286 & 5.613 \\
\hline
\end{tabular}

Keterangan: Huruf superscript yang berbeda pada baris yang sama menunjukkan perbedaan yang nyata $(\mathrm{P}<0,05)$.

*) Hari puncak populasi

$\mathrm{P} 1=$ konsentrasi air lindi $5 \% / \mathrm{L}$ air

$\mathrm{P} 2=$ konsentrasi air lindi $10 \% / \mathrm{L}$ air

$\mathrm{P} 3=$ konsentrasi air lindi $15 \% / \mathrm{L}$ air

$\mathrm{P} 4=$ konsentrasi air lindi $20 \% / \mathrm{L}$ air

$\mathrm{P} 5=$ konsentrasi air lindi $25 \% / \mathrm{L}$ air

Dari Tabel 1 diketahui pemberian air lindi konsentrasi 5\% merupakan kelimpahan sel terendah sebesar 2.580.556 sel $/ \mathrm{ml}$, puncak hari ke-6, dan kelimpahan sel tertinggi sebesar $7.322 .222 \mathrm{sel} / \mathrm{ml}$, puncak hari ke-16. Lamanya hari puncak pada konsentrasi air lindi yang tinggi, disebabkan karena bakteri pengurai membutuhkan waktu lama mengurai materi organik, sehingga ketersediaan unsur hara dalam media kultur waktunya lebih lama. Menurut Meriatna et al., (2018), Efektif Mikroorganisme (EM4) merupakan campuran dari mikroorganisme yang menguntungkan, dan EM4 akan mempercepat proses fermentasi bahan organik, sehingga unsur hara yang terkandung akan mudah terserap.

Semakin besar konsentrasi air lindi yang diberikan, semakin besar pula kesempatan bakteri dalam EM4 untuk melakukan proses dekomposisi, sehingga akan lebih mudah diserap oleh mikroalga untuk pertumbuhan. Sulistiono (2018), kandungan EM4 terdiri dari bakteri fotosintetik, bakteri asam laktat, Actinomicetes, ragi dan jamur fermentasi. Bakteri asam laktat berfungsi untuk fermentasi bahan organik jadi asam laktat, percepat perombakan bahan organik, lignin dan cellulose, dan menekan pathogen dengan asam laktat yang dihasilkan. Berdasarkan analisis sidik ragam (anava) menunjukkan bahwa nilai $\mathrm{F}$ hitung $>\mathrm{F}$ tabel $(\mathrm{P}<0,05)$, berarti pemberian air lindi hasil penyaringan yang difermentasi EM4 dengan konsentrasi berbeda, memberi respon yang berbeda nyata terhadap kelimpahan sel Chlorella sp. Ini menunjukkan air lindi dengan proses penyaringan yang difermentasi EM4 dapat dimanfaatkan sebagai sumber materi organik, untuk pertumbuhan dan bereproduksi mikroalga.

\section{Laju pertumbuhan spesifik $(\mu / \mathrm{hr})$}

Untuk mengetahui laju pertumbuhan spesifik disajikan pada kurva Gambar 2. Dari Gambar 2 menunjukkan laju pertumbuhan spesifik berkisar antara $0,077-0,195 / \mathrm{hr}$, nilai tertinggi didapat pada air lindi konsentrasi $5 \%$ dan terendah konsentrasi $20 \%$. Perbedaan ini dikarenakan dengan pemberian air lindi konsentrasi $5 \%$, materi organik seperti unsur nitrat jumlahnya lebih sedikit dan sel Chlorella sp menyerap dan memanfaatkan unsur hara dalam waktu yang singkat.

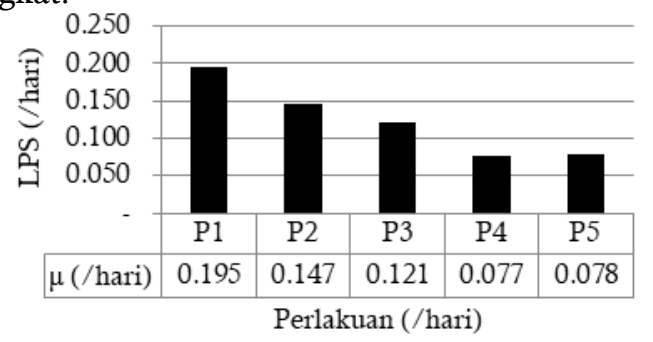

Gambar 2. Grafik Laju Pertumbuhan Spesifik Chlorella sp menurut perlakuan ( $\mu$ (/hari).

Nitrat diubah menjadi nitrit oleh enzim nitrit reduktase yang kemudian dikonversi menjadi ion ammonium, sehingga dapat dimanfaatkan mikroalga. Pemanfaatan nitrat yang optimal akan meningkatkan laju pertumbuhan spesifik mikroalga (Widyantoro et al., 2018). Tingginya laju pertumbuhan spesifik pada konsentrasi 5\%, disebabkan karena hari puncak populasinya lebih singkat, yakni pada hari ke-6. Menurut Aulia et al., (2017), perbedaan laju pertumbuhan spesifik pada setiap perlakuan, disebabkan oleh kemampuan sel dalam menyerap unsur hara yang terdapat dalam media kultur.

Pemberian air lindi dengan penyaringan konsentrasi $10 \%, \quad 15 \%, 20 \%$ dan $25 \%$, laju 
pertumbuhan spesifik lebih rendah dibandingkan konsentrasi 5\%. Perbedaan ini disebabkan karena pemanfaatan unsur hara dengan konsentrasi yang tinggi butuh waktu panjang, sehingga hari puncak populasi sel Chlorella sp juga menjadi lebih lama, yakni pada hari ke-10 hingga hari ke-16.

\section{Biomassa Chlorella sp}

Hasil pengukuran jumlah biomassa sel Chlorella sp selama penelitian disajikan pada Gambar 3.

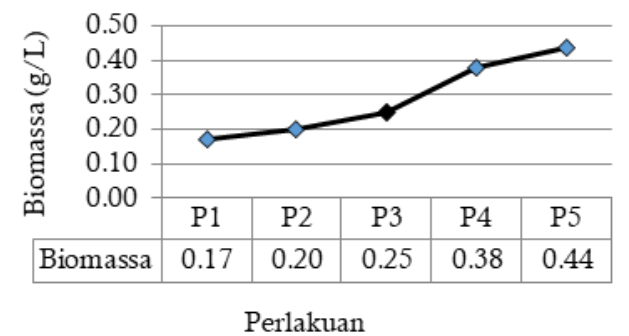

Gambar 3. Jumlah Biomassa Chlorella sp (g/l) menurut perlakuan selama penelitian.

Berdasarkan Gambar 3 diketahui jumlah biomassa sel Chlorella sp tertinggi sebesar 0,44 g/1 pada pemberian air lindi konsentrasi $25 \%$ dan terendah 0,17 $\mathrm{g} / 1$ pada konsentrasi 5\%. Peningkatan konsentrasi air lindi dalam media kultur berpengaruh pada kenaikan jumlah biomassa, karena jumlah materi organik yang diberikan tiap perlakuan juga meningkat. Jumlah biomassa dipengaruhi oleh ketersediaan unsur hara dalam media kultur, seperti unsur nitrogen, fosfat dan lainnya.

Perbedaan jumlah biomassa sel Chlorella sp yang dihasilkan, diduga karena faktor nutrisi berupa nitrat, selain itu juga dipengaruhi oleh faktor-faktor lain yang berpengaruh terhadap produksi biomassa, seperti suhu, $\mathrm{pH}$, cahaya, dan $\mathrm{CO}_{2}$ (Banerjee et al., 2011). Jumlah biomassa berhubungan dengan kelimpahan sel Chlorella sp, hal ini dapat dilihat pada Tabel 1 dan Gambar 1. Semakin meningkat kelimpahan sel, maka semakin besar jumlah biomassa.

\section{Kualitas air lindi Suhu}

Suhu selama penelitian relatif stabil berkisar antara $28-29^{\circ} \mathrm{C}$, karena kultivasi dilakukan dalam satu ruangan, dengan sirkulasi udara yang cukup dan lancar. Prabowo (2009), melaporkan kisaran suhu 25$30^{\circ} \mathrm{C}$ merupakan suhu yang optimal untuk pertumbuhan Chlorella sp dan dapat meningkatkan aktivitas biologisnya dari organisme sebesar 2-3 kali lipatnya. Kisaran suhu tersebut sesuai dengan kisaran suhu kultur Chlorella sp, karena pada kisaran suhu tersebut metabolisme Chlorella sp dapat berlangsung dengan baik. Bila merujuk pada nilai suhu media kultur selama penelitian, suhu mendukung untuk pertumbuhan dan bereproduksi.

pH

Hasil pengukuran $\mathrm{pH}$ media kultur selama penelitian disajikan pada Gambar 4.

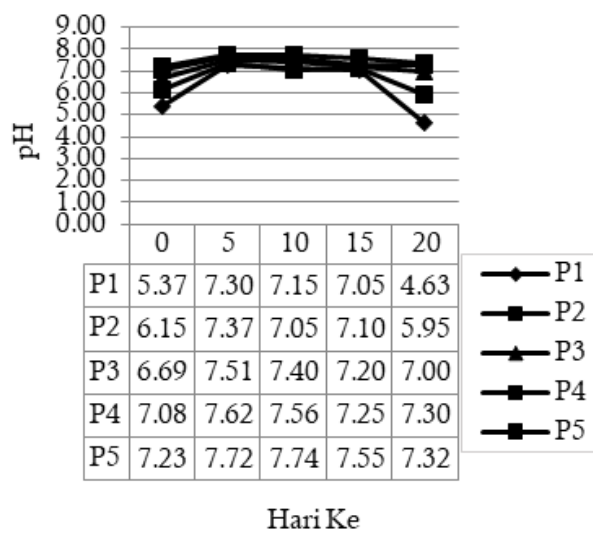

Gambar 4. Nilai pH media kultur selama penelitian menurut perlakuan.

Hasil penelitian menunjukkan $\mathrm{pH}$ media kultur selama penelitian berkisar antara 4,63-7,74. Nilai $\mathrm{pH}$ mengalami kenaikan hingga pengukuran hari ke-5, karena pada fase tersebut terjadi pertumbuhan dan peningkatan jumlah populasi sel Chlorella sp secara cepat, serta berlangsungnya aktifitas fotosintesis dan meningkatnya kandungan oksigen. Nilai $\mathrm{pH}$ media kultur relatif stabil hingga pengukuran hari ke-15, karena sel mikroalga masih mengalami pertumbuhan.

Pengukuran hari ke-20 nilai $\mathrm{pH}$ mengalami penurunan seiring menurunnya pertumbuhan sel Chlorella sp, karena memasuki fase kematian yang disebabkan ketersediaan materi organik dalam media kultur mulai terbatas dan menurun, sehingga hasil proses fotosintesis menurun. Prabowo (2009), melaporkan $\mathrm{pH}$ yang sesuai untuk pertumbuhan sel Chlorella sp berkisar antara 4,5-9,3; Boroh (2019), pada kisaran $\mathrm{pH} 7,88-8,47$ sel Chlorella sp dapat tumbuh dengan baik. Merujuk pada nilai $\mathrm{pH}$ media kultur selama penelitian, nilainya mendukung untuk proses metabolisme dan pertumbuhan sel.

\section{Oksigen terlarut (DO)}

Hasil pengukuran kandungan oksigen terlarut selama penelitian dapat dilihat dalam bentuk grafik Gambar 5.

Kandungan oksigen terlarut (DO) media kultur selama penelitian berkisar antara 3,6-7,9 mg/1. Penambahan air lindi dengan penyaringan konsentrasi $25 \%$ yang difermentasi EM4, mulai awal hingga akhir pengukuran kandungan oksigen terlarut mengalami peningkatan. Meningkatnya nilai oksigen terlarut memiliki korelasi dengan kelimpahan sel Chlorella sp, karena sumber terbesar oksigen dalam media kultur berasal dari hasil proses fotosintesis mikroalga. Menurut Widiyanto et al., (2014), sumber oksigen dalam media kultur berasal dari proses fotosintesa dan tergantung pada ketersediaan klorofil. 


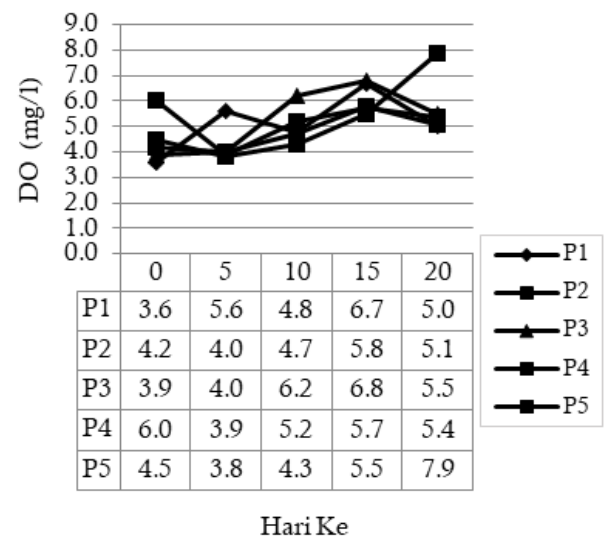

Gambar 5. Oksigen terlarut (mg/l) menurut perlakuan dan waktu pengukuran.

Ketersediaan oksigen di dalam media kultur merupakan faktor penting untuk fitoplankton, karena secara langsung dipakai sebagai bahan untuk membentuk molekul-molekul organik melalui proses fotosintesis. Oksigen terlarut optimum bagi pertumbuhan fitoplankton berkisar 4,65-6,27 mg/l (Richmond, 2004). Kandungan oksigen terlarut pada akhir pengukuran mengalami penurunan, kecuali pada konsentrasi air lindi $25 \%$ terjadi kenaikan. Rendahnya kandungan oksigen pada pemberian air lindi konsentrasi 5\%, dikarenakan jumlah materi organik yang diberikan rendah. Menurut Istirokhatun et al., (2017), keberadaan zat-zat organik yang secara ilmiah dapat dioksidasi melalui proses mikrobiologis, sehingga mengakibatkan berkurangnya oksigen terlarut di perairan.

\section{Nitrat}

Untuk mengetahui hasil kandungan nitrat medi kultur selama penelitian disajikan pada Gambar 6 .

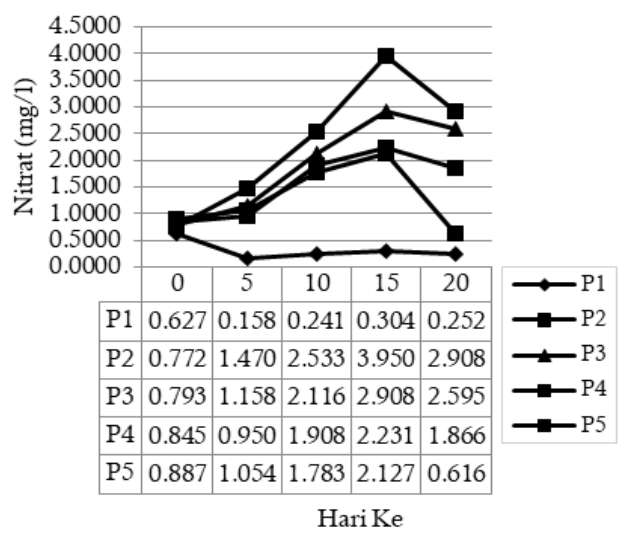

Gambar 6. Kandungan nitrat (mg/l) menurut perlakuan dan waktu pengukuran.

Kandungan nitrat awal dan akhir pengukuran berkisar antara 0,6271-0,8875 mg/1 dan 0,2521-2,9083 $\mathrm{mg} / 1$. Bila ditingkatkan konsentrasi air lindi pada awal pengukuran, menyebabkan kandungan nitrat tiap perlakuan mengalami peningkatan, karena materi organik pada media kultur juga meningkat.
Pemberian air lindi dengan penyaringan konsentrasi 5\% yang difermentasi Efektif Mikroorganisme-4, menunjukkan kandungan unsur nitrat mengalami penurunan hingga berakhirnya penelitian. Penurunan unsur nitrat pada konsentrasi 5\%, disebabkan karena dengan konsentrasi air lindi yang rendah, ketersediaan materi organik pada media kultur menjadi terbatas dan tidak mencukupi untuk tumbuh dan pembiakan sel mikroalga. Selanjutnya penurunan unsur nitrat dalam media kultur, dapat disebabkan adanya pengaruh penyaringan dan proses fermentasi EM4, yang menyebabkan zat terlarut dan bahan-bahan tersuspensi pada air lindi mengalami penurunan. $\mathrm{Hal}$ ini terlihat adanya penurunan, seperti kandungan COD awal pengukuran sebesar 88,46-96,68 mg/1 dan akhir 80,00-94,60 mg/1, sedangkan nilai BOD awal pengukuran sebesar 4,48-6,12 mg/1 dan akhir 2,86$5,30 \mathrm{mg} / 1$.

Kandungan nitrat tiap perlakuan selama kultur berkisar antara 0,1583-3,9500 mg/l. Tambaru (2008), melaporkan bahwa untuk mendukung pertumbuhan sel Chlorella sp dapat tumbuh dengan baik, kandungan nitrat berkisar antara 0.9-3.5 ppm. Bila kadar nitrat di bawah $0.1 \mathrm{ppm}$ atau di atas $45 \mathrm{ppm}$, maka nitrat dapat merupakan faktor pembatas kesuburan.

Pada pemberian air lindi konsentrasi 10\%, 15\%, $20 \%$ dan $25 \%$, kandungan unsur nitrat mengalami peningkatan hingga hari ke-15. Hal ini disebabkan karena air lindi dengan penyaringan yang difermentasi EM4, proses dekomposisi materi organik berlangsung lambat, sehingga proses pembentukan nitrat dalam media kultur berjalan dalam waktu yang lama. Selanjutnya pada konsentrasi air lindi 15\%, 20\% dan $25 \%$ kenaikan unsur nitrat lebih rendah dibanding konsentrasi $10 \%$, hal ini disebabkan karena semakin meningkat jumlah materi organik yang diberikan, kemampuan bakteri untuk mengurai materi organik juga terbatas.

Semakin rendah atau tinggi konsentrasi air lindi pada media kultur, kandungan nitrat mengalami penurunan, ini menunjukkan kebutuhan unsur hara untuk pertumbuhan sel mikroalga dibutuhkan dalam jumlah tertentu. Sylvester et al., (2002), ketersediaan unsur hara pada media kultur dalam jumlah tertentu mutlak diperlukan, sehingga kelebihan atau kekurangan unsur hara dalam media kultur akan mempengaruhi pertumbuhan kultur mikroalga.

Pemanfaatan unsur nitrat pada media kultur, diketahui setelah dilakukan pengukuran hari ke-15 sampai ke-20, yang ditandai dengan menurunnya unsur nitrat pada setiap perlakuan. Penurunan unsur nitrat dikarenakan mikroalga memanfaatkan untuk pertumbuhan dan bereproduksi. Acivedo et al., (2017), mengatakan mikroalga dapat memanfaatkan senyawa organik dan anorganik yang terlarut dalam air limbah untuk pertumbuhan.

\section{Fosfat}

Hasil pengukuran kandungan fosfat disajikan pada Gambar 7. Selama penelitian kandungan fosfat 
berkisar antara $0.042-5,8518 \mathrm{mg} / \mathrm{l}$. Fosfat dan nitrat merupakan nutrien penting untuk pertumbuhan dan bereproduksi mikroalga. Menurut Aprilliyanti et al., (2016), kadar fosfat yang optimal untuk pertumbuhan fitoplankton berkisar antara 0,27-5,51 mg/1.

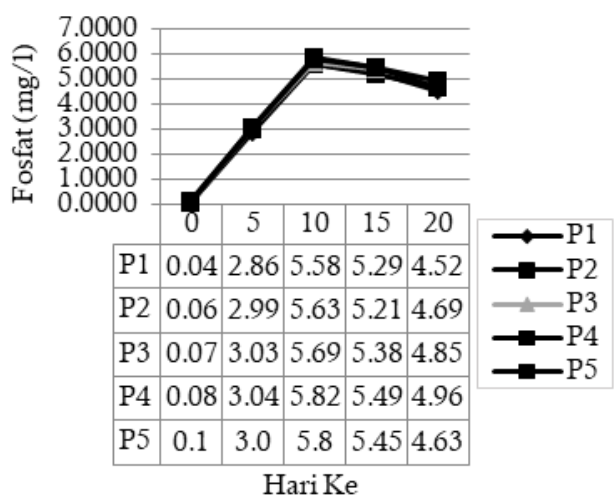

Gambar 7. Kandungan fospat (mg/l) menurut perlakuan dan waktu pengukuran.

Dari Gambar 7 diketahui bahwa, kandungan fosfat mengalami peningkatan pada seluruh perlakuan hingga pengukuran hari ke-10. Meningkatnya kandungan fosfat disebabkan karena unsur fosfat belum mengalami penguraian secara sempurna, sehingga mikroalga belum dapat menyerap untuk proses metabolisme.

Pengukuran hari ke-15 hingga ke-20 kandungan fosfat mengalami penurunan untuk seluruh perlakuan, menurunnya kandungan fosfat dapat disebabkan oleh pengaruh penyaringan dan fermentasi oleh bakteri pengurai, sehingga unsur fosfat pada media kultur lebih mudah diserap oleh mikroalga. Faktor lain yang menyebabkan lambatnya unsur fosfat dimanfaatkan oleh mikrolga, karena unsur fosfat termasuk salah satu unsur kimia yang lambat mengurai. Selain itu juga diduga unsur fosfat dalam larutan air lindi belum mengalami proses dekomposisi secara sempurna. Sehingga larutan fosfat dalam media kultur belum dapat diserap oleh sel Chlorella sp.

Siklus fosfor yaitu siklus yang paling lambat jika dibandingkan dengan beberapa siklus biogeokimia lainnya (Gustianysah, 2020). Konsentrasi P total mengalami penambahan atau penurunan, kemungkinan dipengaruhi oleh aktivitas mikroba dalam larutan dan juga dipengaruhi oleh aktivitas yang dilakukan oleh tanaman (Avivi et al., 2010).

\section{Logam berat $(\mathrm{Cu}, \mathrm{Fe}, \mathrm{Mn}, \mathrm{Zn}, \mathrm{Cd})$}

Hasil analisis logam berat menurut perlakuan, pada pengukuran awal hingga akhir penelitian, nilainya sama untuk seluruh unsur logam berat, yaitu $<0,2 \mathrm{mg} / \mathrm{l}$. Nilai ini berada di bawah ambang batas baku mutu, menurut Permentan No.70/2011, tentang baku mutu pupuk organik cair; dan Permen LHK No.P.59/2016, tentang baku mutu lindi.

\section{KESIMPULAN}

Pemanfaatan air lindi hasil penyaringan yang difermentasi (EM4) dengan konsentrasi berbeda memberi pengaruh terhadap pertumbuhan dan kelimpahan sel Chlorella sp. Kelimpahan tertinggi didapat pada pemberian air lindi konsentrasi 25\% dengan kelimpahan sebesar $7.322 .222 \mathrm{sel} / \mathrm{ml}$, puncak hari ke-16. Kelimpahan terendah pada air lindi konsentrasi 5\% sebesar $2.580 .556 \mathrm{sel} / \mathrm{ml}$, dengan puncak hari ke-6. Laju pertumbuhan spesifik selama penelitian sebesar 0,077-0,195/hari. Pertumbuhan dan kelimpahan sel Chlorella sp dipengaruhi oleh ketersediaan unsur hara, yang terdapat pada air lindi sebagai sumber materi organik.

\section{UCAPAN TERIMAKASIH}

Penulis mengucapkan terimakasih kepada Direktorat Penelitian dan Pengabdian Masyarakat (DPPM) Universitas Islam Riau, yang telah memberi bantuan pendanaan penelitian dosen. Terimakasih juga disampaikan pada saudara Rizka Avif Putri Hsb. S.Pi staf labor Mikroalga Faperta UIR dan Khairul Hadi mahasiswa Prodi Budidaya Perairan Faperta UIR yang telah membantu pelaksanaan penelitian ini.

\section{DAFTAR PUSTAKA}

Acivedo, S., Pino, N.J., \& Panuela, G.A. (2017). Biomass Production of Scenedesmus sp. and Removal of Nitrogen and Phosphorus in Domestic Wastewater Remocion de Nitrogeno, fosforo by Produccion de Biomasa de Scenedesmus sp. en Agua Residual Domestica. Environmental Engineering. 193 (1): 185-193. http://www.scielo.org.co/scielo.php?script=sci_arttext\&pid=S012330332017000100185.

Aprilliyanti, S., Soeprobowati, T.R \& Yulianto, B. (2016). Hubungan Kemelimpahan Chlorella sp Dengan Kualitas Lingkungan Perairan Pada Skala Semi Masal di BBBPBAP Jepara. Jurnal Ilmu Lingkungan. 14 (2): 77-81.

https://doi.org/10.14710/ji1.14.2.77-81

Aulia, M., Istirokhotun, T \& Sudarno. (2017). Penyisihan Kadar COD dan Nitrat Melalui Kultivasi Chlorella sp dengan Variasi Konsentrasi Limbah Cair Tahu. Jurnal Teknik Lingkungan. 6 (2): 1-9. https://www.neliti.com/id/publications/140791/penyisihan-kadar-cod-dan-nitrat-melaluikultivasi-chlorella-sp-dengan-variasi-kon

Avivi, S., Suyani, I.S \& Winarso, S. (2010). Efek Bakteri Pelarut Fosfat Terhadap Pertumbuhan Aspergillus flavus Pada Perkecambahan Kacang Tanah. Jurnal HPT Tropika. 10 (1): 64-72. https://doi.org/10.23960/j.hptt.11064-72 
Banerjee, S., Hew, W.E., Khatoon, H., Shariff, M \& Yusoff, F.M. (2011). Growth and Proximate Composition of Tropical Marine Chaetoceros calcitrans and Nannochloropsis oculata Cultured Outdoors and Under Laboratory Conditions. African Journal of Biotechnology. 10 (8): 1375-1383.

https://www.ajol.info/index.php/ajb/article/view/92946.

Boroh, R., Litaay, M., Umar, M.R \& Ambeng. (2019). Pertumbuhan Chlorella sp. Pada Beberapa Kombinasi Media Kultur. Bioma: Jurnal Biologi Makassar. 4 (2): 129-137. https://doi.org/10.20956/bioma.v4i2.6759.

Dimiati, D.D \& Hadi, W. (2017). Uji Pemanfaatan Pupuk Organik Cair Lindi dengan Penambahan Bakteri Starter Terhadap Pertumbuhan Tanaman Hortikultura (Solanum melongena dan Capsicum frutescens). Jurnal Teknik ITS. 6 (2): 349-354. 10.12962/j23373539.v6i2.25199

Gustianysah. (2020). Siklus Fosfor: Pengertian, Peranan, Sifat, Proses dan Manfaatnya. https://failfaire.org/siklus-fosfor. Diakses, Maret 2021.

Istirokhatun, T., Aulia, M \& Sudarno. (2017). Potensi Chlorella sp Untuk Menyisihkan COD dan Nitrat Dalam Limbah Cair Tahu. Jurnal Presipitasi. Media Komunikasi dan Pengembangan Teknik Lingkungan.14 (2):88-96.

https://doi.org/10.14710/presipitasi.v14i2.88-96

Liu, L., Wenyu, L., Yichen, Z., Jing, Z., \& Fujie, Z. (2015). Effect of Nitrogen-containing Compounds on Growth Characteristic of the Oleaginous Microalga Chlorella ellipsoidea. Electronic Journal of Biology. 11 (1): 1-7.

https://ejbio.imedpub.com/effect-of-nitrogencontaining-compounds-on-growth-characteristic-ofthe-oleaginous-microalga-chlorella-ellipsoideasd0701.php?aid $=6012$

Meriatna., Suryati \& Fahri, A. (2018). Pengaruh Waktu Fermentasi dan Volume Bio Aktivator EM4 (Effective Microorganisme) pada Pembuatan Pupuk Organik Cair (POC) dari Limbah BuahBuahan. Jurnal Teknologi Kimia. 7 (1): 13-29. https://doi.org/10.29103/jtku.v7i1.1172

Meritasari, D., Mubarok, A.S., Sulmartiwi, L \& Masithah, E.D. (2012). Pengaruh Pemberian Pupuk Cair Limbah Ikan Lemuru (Sardinella sp) Dengan Dosis yang Berbeda Terhadap Pertumbuhan Chlorella sp. Jurnal Ilmiah Perikanan dan Kelautan. 4 (1): 27-32.

http://dx.doi.org/10.20473/jipk.v4i1.11579

Mujiatul, M. (2013). Peningkatan Kadar N, P dan K Pada Pupuk Cair Limbah Tahu Dengan Penambahan Tanaman Matahari Meksiko (Thitonia diversivolia), Skripsi. Universitas Negeri Semarang, Semarang.

Mukhlis, A., Abidin, Z \& Rahman, I. (2017). Pengaruh Konsentrasi Pupuk Amonium Sulfat Terhadap Pertumbuhan Populasi Sel Nannochloropsis sp. Jurnal
Biowallacea Jurnal Ilmiah Ilmu Biologi. 3 (3): 149 155.

Peraturan Menteri Pertanian. 2011. Nomor. 70/Permentan/SR.140/10/2011. Tentang Pupuk Organik, Pupuk Hayati dan Pembenah Tanah. 109 hal.

Peraturan Menteri Lingkungan Hidup dan Kehutanan Republik Indonesia. 2016. Nomor. P.59/Menlhk/Setjen/Kum.1/7/2016. Tentang Baku Mutu Lindi Bagi Usaha dan/atau Kegiatan Tempat Pemrosesan Akhir Sampah. 12 hal

Prabowo, D.A. (2009). Optimasi Pengembangan Media Untuk Pertumbuhan Chlorella sp Pada Skala Laboratorium. Program studi Ilmu dan Teknologi Kelautan Fakultas Perikanan dan Ilmu Kelautan. Institut Pertanian Bogor. Bogor. 108 hal.

Richmond, A. (2004). Biological Principles of Mass Cultivation. In: Richmond A, editor. Handbook of Microalgal Culture: Biotechnology and Applied Phycology. Blackwell Publishing Ltd. London. pp. 125-177.

Steel, R.G.D. \& Torrie, J.H. (1993). Prinsip dan Prosedur Statistika. Suatu Pendekatan Masalah Biometrik. Gramedia, Jakarta.

Sugiharto. (2020). Chlorella vulgaris dan Spirulina platensis: Kandungan Nutrisi dan Senyawa Bioaktifnya Untuk Meningkatkan Produktivitas Unggas. Wartazoa. 30 (3): 123-138.

Sulistiono, E. (2018). Pengolahan Limbah Cair Tahu Dengan Menggunakan Effective Microorganism Organik (EM4 Organik). Jurnal Pengabdian Masyarakat. 1 (1): 22-28. https://doi.org/10.30736/jab.v1i01.30

Sylvester, B., Nelvy, D \& Sudjiharno. (2002). Biologi Fitoplankton, Budidaya Fitoplankton dan Zooplankton. Balai Budidaya Laut Lampung. Makara, Teknologi. 9: 3-23.

Tambaru, R. (2008). Dinamika Komunitas Fitoplankton Dalam Kaitannya Dengan Produktivitas Perairan di Perairan Pesisir Maros Sulawesi Selatan. Disertasi. Pasca Sarjana IPB. Bogor. (tidak diterbitkan)

Widiyanto, A., Susilo, B \& Yulianingsih, R. (2014). Studi Kultur Semi-Massal Mikroalga Chlorella sp Pada Area Tambak Dengan Media Air Payau (Di Desa Rayunggumuk, Kecamatan Glagah, Kabupaten Lamongan). Jurnal Bioproses Komoditas Tropis. 2 (1): 1-7.

https://jbkt.ub.ac.id/index.php/jbkt/article/view/127

Widyantoro, H., Wijayanti, M \& Dwinanti, S.H. (2018). Modifikasi Media Spirulina platensis Sebagai Upaya Pemanfaatan Air Limbah Budidaya Ikan Lele. Jurnal Akuakultur Rawa Indonesia. 6 (2): 153164. https://doi.org/10.36706/jari.v6i2.7159.

Wood, A.M., Everroad, R.C \& Wingard, R.M. (2005). Measuring Growth Rates in Mikroalgal Cultures. In: Algal Culturing Techniques (Andersen, R.A. Ed). Elseviers Acad. Press. pp. 269-284. 